\title{
THE TRANSLATION OF THE EAST IN MOZAMBICAN LITERATURE $^{1}$
}

\author{
NAZIR AHMED CAN \\ Universidade Federal do Rio de Janeiro \\ CNPq - FAPERJ - CAPES \\ nazircan@letras.ufrj.br \\ ORCID: 0000-0002-7509-9688
}

\section{ABSTRACT}

For many scholars who have studied the practice, translation is, among many other things, a form of poetic transcreation. In a similar way, the landscape, due to its ability to generate meaning, invites the writer to move from one cultural code to another. Focusing on contemporary Mozambican literature, with special emphasis on the production of João Paulo Borges Coelho, Luís Carlos Patraquim and Eduardo White, this article aims to observe how the spaces of the East are "translated" in the prose and poetry of the post-independence period. We will also draw attention to the forms of late Orientalism that emerge in this literature.

KEYWORDS: Mozambican literature, translated otherness, orientalism, João Paulo Borges Coelho, Luís Carlos Patraquim, Eduardo White.

Due to the material difficulties that affect the literary institution in most African countries, the writer lives with a structural disadvantage in his creative process: writing about a space that is close to him for a distant reader. ${ }^{2}$ To deepen the complexity, this reader usually has only a distorted frame of reference, provided by the media or by imperial literature. In line with what defend Tanqueiro (2003) and Hernández (2007), we could affirm that in contexts of production like this, so affected by contradiction, the writer is confronted with problems similar to those of the translator. Although his work does not correspond to the classical translation that materializes in another publication, but to a mediation process ${ }^{3}$ performed within the work itself, the writer, just

${ }^{1}$ This study was financed in part by the Coordenação de Aperfeiçoamento de Pessoal de Nível Superior - Brasil (CAPES) - Finance Code 001, Project 88887.364731/2019-00, Institutional Internationalization Program - CAPES-PrINT. As this text was revised between May and July 2020, it was also supported by National Council for Scientific and Technological Development (CNPq - Brazil, Bolsa de Produtividade em Pesquisa - Nível 2, Process 307217/2018-3) and by Rio de Janeiro Research Foundation (FAPERJ - Brazil, Bolsa Jovem Cientista do Nosso Estado, Process E26/203.025/2018).

${ }^{2}$ In this regard, read Coelho (2009: 57-67).

${ }^{3}$ According to Antoine Hennion (1993: 10), the notion of mediation is more appropriate to describe the artistic object, since it accounts for the infinity of interactions that can be observed in the musical world: between musicians, between these and their audience or between a musician and his instrument. On the articulation between those qualitative and quantitative elements in the literary field, and on the role of sociability networks, see Marneffe and Denis (2006). 
like the translator, takes a predominantly demanding or exotic posture. Often, pressures from the publishing market guide the writer's options. With regard to the representation of geography and its related knowledge, the beautiful summary of Ruy Duarte de Carvalho in the book The chamber, the writing and the said thing... tapes, texts and lectures [A câmara, a escrita e a coisa dita... fitas, textos $e$ palestras] (2008) shows the challenge that certain spaces pose to the writer committed to what he reads, touches and listens to:

The landscape questioned me: to deal with it, to understand it, to make the landscape and its deciphering the place of life, only knowing how they saw it, read it, said those who looked at it from other idioms, from other languages, other understandings shaped by those same landscapes and those same languages............. find a way to say those landscapes, in Portuguese, what would be said in other languages or what they said in other languages as it could not be otherwise $(2008: 20)^{4}$

The complexity becomes even greater when the authors propose to build international spaces (from other "Africas" or from Asia, for example) that may house the societies described in their narratives. Focusing on contemporary Mozambican literature, we will reflect on how the East ${ }^{5}$ integrates into prose and poetry. Although more briefly, we will also draw attention to the forms of late Orientalism that emerge in this field of production. With the notion of "Orientalism" borrowed from Edward Said (2003, 2011) we refer here to domestication modes, with specific ideological purposes, of other people's imaginary.

The orientalist vocation of Mozambican literature, which distinguishes it in Portuguese-speaking contexts, derives from a specific socio-historical and geographical fact: the coexistence in the national territory of populations of African origin with Persian, Gujarati, Vanyan, Malabar, Chinese and Arab communities etc. Since this contact takes place mainly in the north of the country, the idea of the East has been associated in literature with the material and symbolic universe of the Island of Mozambique. ${ }^{6}$ The small island of three

${ }^{4}$ With the exception of the fragments of "The Enchanted Cloth," by João Paulo Borges Coelho (2020), which was recently translated by David Brookshaw, all quotes in this article are translated by ourselves.

${ }^{5}$ For any analysis of African literatures trajectory from a spatial perspective, especially when the "East" is present, it is necessary to emphasize that the name of this macrospace is, in itself, a reductionist invention that delimits its belonging to the West, in the same way that "North" and "South" are nowadays categories widely used, despite the contradiction they bring: after all, if the Earth revolves around itself, there is no way to rigidly separate these two "places." Therefore, the East will be analysed in this article in its geographical, historical and cultural dimensions, on the one hand. But we will not disregard, on the other hand, one of its most known, derogatory and eminently political derivations: Orientalism.

6 In recent years, there were several perspectives examining this unique and complex production. We can mention, as an example, the studies of Chaves (2002), Leite (2003: 123-144), 
kilometres was the scenario for an authentic "transnational crossroads" (Noa 2012: 4) and a kind of threshold, representing a crossing point that connected the African continent to Asia. This place inspired a significant part of the local artistic production, both by two generations of authors who declared themselves "the Indian Ocean poets" (such as Rui Knopfly, Orlando Mendes and Vergílio de Lemos, in the first stage; and Luís Carlos Patraquim, Eduardo White and Júlio Carrilho, in the second stage) and from some authors who, in the following decades, inherited this "tool" of expression (Nelson Saúte, Adelino Timóteo, Guita Jr., Sangare Okapi etc.). On the one hand, due to its structural impact on the literary field, foreign characters and cultures were driven to unusual protagonism. On the other hand, the black-African experience of that region has become somewhat rarefied ${ }^{7}$ and the exclusion processes, also on the Island of Mozambique, that were fostered between the center and periphery (or the "asphalt" and the caniços, the poor neighbourhoods), were rarely represented. At the same time and paradoxically, this poetry rarely represented territories outside national borders. In general, the environment chosen was the island. That is the reason why the reality of other spaces at the Indian Ocean has only been partially incorporated, mostly through figuration and often the stereotyping (or strategically essentializing) of characters who, being national and simultaneously diasporic (such as communities of Indian origin, for example), suggest some cultural practices from neighboring territories. ${ }^{8}$

However, this kind of introverted insularity concerns specially the last century. In the last 20 years, although not without impasses, as we will see, there has been an effective opening of Mozambican literary geography to the outside, and in all genres. From India to Saudi Arabia, through Tanzania, Somalia, Yemen, Kenya, Comoros, Japan, China, Macau, Pakistan or Oman, just to name a few territories, several international spaces have been incorporated in recent decades. If until 1975 the inscription of the East in poetry had as priority target the Portuguese colonial regime, as long as such inscription suggested that the phenomenon of hybridity preceded the arrival of the first Europeans in Mozambique, in the post-colonial period the possibilities of representation and its objectives has been expanded: this movement was motivated by both national political elites, who conservatively associate the notions of "race" and "geography" to legitimize, in the position of "originators", their maintenance in power, as well as by the desire of the authors themselves to rethink the

Apa (1989), Falconi (2008), Mendonça (2011) and Noa (2012). Two academic journals in Brazil, Metamorfoses (2002) and Remate de Males (2019), also dedicated a thematic dossier to the Island of Mozambique.

7 On this aspect, see Cabaço (2002: 58-59).

8 On the representation of "Indian" in Mozambican literature, see Can (2012: 217-230).

${ }^{9}$ In this regard, see Mbembe (2001: 174). 
nation in a more extensive space of exchanges and discussions. Finally, as mentioned above, it is still possible to observe that the "oriental pulse" did not inhibit the intrusion of some forms of "late orientalism" in Mozambican literature. Thus, instead of grouping the authors around a community idea of "Indian Ocean", we will examine this production from the angle of displacement, tension, contradiction and mediation. We will see how this works in Mozambique literary projects that we could call "counter-orientalist", such as those by João Paulo Borges Coelho and Luís Carlos Patraquim, which coexist with others that, on the contrary, assume a more markedly exotic aspect, such as those by Eduardo White.

Author of an already vast prose production, especially in the novel, which includes a reflection on territories in East Africa and Asia, João Paulo Borges Coelho reads the Mozambican nation no longer as an exclusive result of the Portuguese empire (following a fatalistic line) nor as a result of itself (following an essentialist logic), but in function of the power dynamics that reproduce on an interplanetary scale. It is through this path that the writer investigates aesthetically in "The Enchanted Cloth" (2020) ["O pano encantado" (2005)], the first story of Indian Ocean Traces-North/South [Índicos Indícios-Setentrião /Meridião], the almost millennial split that involves the Islamic brotherhoods of the north of the country, in East Africa and Asia and whose effects today are more or less known around the world. ${ }^{10}$ In addition to exploring this theme, unique in the context of Portuguese-language literatures, the author sets part of the narrative on the Island of Mozambique, an area until then covered only by poets. By offering clues about the plurality of social positions and political, identity and religious backgrounds of Muslim communities, 11 "The Enchanted Cloth" is a story that represents silent conflicts between two protagonists.

Rashid, owner of "The Year 2000 Tailor's Shop" (an enterprise with a future name that is already outdated), and Jamal, the young assistant, coexist in a gloomy and old workspace. The first character, Afro-Muslim, embodies a

\footnotetext{
${ }^{10}$ It should be noted that, also in prose, Mia Couto O outro pé da sereia, of 2006, places Goa as a species of origin of Mozambican nationality, although divided into several pieces that are lost in the waters of the Indian Ocean. In this novel, the ocean and Goa are no longer a passive scenario of the described passages, as was usual in colonial aesthetics, but as the scenography of an identity in process. That is, geography is personified and acquires an aspect of protagonism. Based on a very well-assembled structure and the abandonment of the neologist strategy that made this author celebrated, two parallel stories are intertwined, both originating in a statue that travels from Goa to Africa. This fractured object will be the bridge between both contexts and both temporalities. David Brookshaw defines the intertwining of these stories as "a kind of myth that founds the Afro-Indian 'miscegenation' process in the country" (2008: 134). In fact, in his production (and now we refer to an oeuvre that includes poetry, short stories, chronicles and novels), Mia Couto seeks to imbue the lost and apparently unimportant artefacts with memory to suggest the need for approximation between communities of different origins that coexist in Mozambique.

${ }^{11}$ On Muslim communities in contemporary Mozambique, see Macagno (2006).
} 
large part of the stereotypes that in colonial and post-colonial Mozambique were attributed to communities of Asian origin, especially Indians. The description of his movements, always connoted with mystery, exception and duplicity (repeatedly inscribed in the asyndetic phrase, the act of leaving out the customary conjunctions between sentence elements: for example, he has a pen that "measures and notes", "double-headed", "one red and one blue"), places Rashid in a sphere contrary to that of the narrator, who behaves as a foreigner, and that of Jamal. The boss is thus linked satirically to money diversion and illegal storage of products. Alliances with the old settler are also not forgotten. At the opposite end of the dark room is the unfathomable Jamal. Because he despises his boss's hybrid religious practices and cannot move around, the young man spends almost all day pedalling the old Singer machine, clandestinely embroidering his sacred trip to Mecca in a cloth. That is, alongside faith, art will be the only way for Jamal to alleviate the distortion of his reality, which involves routine gestures and forced submission.

Departing from his neighbourhood Macaripe, the path of his needle travels through close territories, such as Zanzibar, Kenya, Somalia, Yemen and Saudi Arabia (Mecca), to return to Macaripe, starting point and arrival. With this itinerary, Jamal intends to "show that it was necessary to go and come back in order for everything to make sense and for him to be a haji, a believer who has visited the City" (2020: 29). The path is circular, therefore, and the Indian Ocean replaces the desert as a space of epiphany. With the needle, affective geographies that would otherwise be inaccessible are recovered, differences are signalled and times are harmonized in a rational building where history of an origin is reaffirmed and truth is orchestrated. The haunting outline embroidered by Jamal allows us, therefore, to observe the map of his Islam, his brotherhood, and from it the history of the various forms of religious expansion produced by rival dikiris, the other brotherhoods, including that of his boss.

On the other side of the cloth, the young man reinterprets the story of his dikiri, the Shadhuliyya brotherhood, whose origin goes back to the distant year of 1258, "truth or legend" (2020: 30), as the narrator comments, always willing to dismantle essentialisms. A surprising layout signals the presence of historical figures, among whom Shaykh Ma'ruf, "a direct descendant of Fatima, the Prophet's beloved daughter" (2020: 30), at the heart of the discussion about what is the true version of the Islam:

This story could have been like the dense, silky lock of a woman's hair, all the dikiri rolling forward towards the future to create one vast, pure brotherhood. That is what could have happened, but of course it didn't. And while two dark branches head off on their own in disarray - the Naquira of Mr Rashid, his boss, ever more lost to African licentiousness, the Qadiriyya of Abdurahman, kow-towing ever more in the service of infidel overlords - in the centre, a delicate but pure white embroidery represents the Shadhuliyya Madaniyya, Jamal's brotherhood, unpolluted and insuperable in its defence of the faith. (2020: 32-33) 
Apart from aestheticizing the existence of a holy geography, Jamal's cloth portrays a divided Islam, in contrast to the artistic representations of hybridism in the region. By advancing arguments that sacralize identity positions, Jamal also institutionalizes a temporality and invents a truth, with well-demarcated borders and boundaries. However, Rashid discovers the cloth, embroidered during many working hours, and punishes Jamal. In addition to not being able to fulfil his dream of being a true haji, the young man sees his unfinished work being sold by his boss to a group of Italian tourists who pass by ("Guarda che bello", they say) and who do not know the symbolic weight of the cloth. From this situation a new crisis arises, the gap between the young and the old becomes irreducible, the violence is announced in the brightness of the scissors that are wielded against the boss and the clientele ("So that the purity of his solitary designs may therefore be fulfilled"; 2020: 35) and the bridge that connects the Island to the territory grows a few centimetres, offering the anonymous Muslims of the caniço the physical dimension of isolation:

it is the bridge that contains all the mystery, for by joining the two sides, it also makes us remember we are separated. Without a bridge, it would be a whole world in itself; with it, the Island became an island, a closed space that one can only enter or leave by crossing the bridge. (2020: 11)

In short, the bridge here no longer symbolizes the encounter, but its opposite, the partition, the segregation, the unequal "distribution of the sensible" (Rancière 2000: 9). If any effective subversive gesture depends on prior knowledge of the predominant version, or the doxa, what is reported in this narrative is the reverse process. Of a conservative nature, Jamal's subversion re-enables or rehabilitates a version. After all, the work embroidered by the young man, who becomes an anti-hero with no voice or political representation to support his case, is done in hiding from the boss Rashid. Nevertheless, it leads to the creation of a doxa, because it is linked to a radical message of religious and racial purity. Due to the complex strategy of representation elected, João Paulo Borges Coelho differs from earlier poets on Mozambique Island. More than the intercultural encounter, sung in so many Mozambican verses since the 1950s, the author rethinks resistance to hybridism in a context of intra-community violence and division.

Merging knowledge of multiple art forms (embroidery, painting, cartography) with the other no less complete art form of writing, João Paulo Borges Coelho questions, moreover, that "space/niche" that is rarely claimed by literature, of a pure place for himself and for his community. Along the lines of authors from the same region (such as the South African John Maxwell Coetzee, the Malagasy Jean-Luc Raharimanana, the Mauritian Barleen Pyamotoo, the Comorian Abdourahman A. Waberi) or authors who share the same language (such as the Angolan Ruy Duarte de Carvalho), the Mozambican writer abandons the didactic strategy of giving voice to the oppressed, because he 
senses in this gesture the exercise of a new hegemony. Naturally, this option opens up new authorial challenges. After all, how to recreate the fate of certain characters who say little or nothing? In this specific case, we observe that Jamal is the symmetrical contrary of a phenomenon characteristic of our contemporaneity: the cult of mediatization and ostentation, which, according to António Cabrita, stands today as the exclusive nucleus of perception and memorization (Cabrita 2017). It is a protagonist who also no longer joins others in a cry for order, as occurred in the anti-colonial aesthetics of Portuguesespeaking African countries, but perhaps it is the opposite of that. To the rhythm of the Singer machine, an object that accentuates the contradiction of that space, Jamal pushes the narrative into the sphere of "introspective sound, closer to the oriental polarization" (Cabrita 2017) on which Cabrita also reflects. This is, moreover, and still according to the Portuguese poet and essayist based in Maputo, the most paradoxical fact of silence: it only exists in relation. Alone, silence is nothing more than the wind, which, to be heard, "needs a tree, and the air to shock in its branches". For this reason, as in Sufi poetry, the protagonist's silence "is not the opposite of sound or word, but rather an embryonic position, which precedes and prepares the expression" (Cabrita 2017). In the case of Jamal, that is an expression of fanaticism and violence. Thus, João Paulo Borges Coelho achieves something rare these days: experiment on the thematic level and in the formal field, because, as we know, his work constitutes a severe counterattack to the notion of purity.

The same is true with Luís Carlos Patraquim, arguably the great name of national poetry alongside José Craveirinha if we stick to the transversality of forms and themes covered in his already extensive career. In The song of Zefanias Sforza [A canção de Zefanias Sforza], a novel published in 2010, the Mozambican East - specifically the urban area of Maputo - is portrayed.

Here, its symbolic impact is not given by the sea, as is usually represented in the poetry of the country, but by the air, moving a narrative that revolves around a solitary man. As also happens in his poetry, the geographies of displacement and confinement that are inscribed in the novel, instead of opposing each other, operate in a dialectical key to indicate the experience of the internal exile. The Zefanias' balcony is the "profane cloister, therefore open" (2010: 129) from where he prepares his disturbing "derivations" of Maputo, the region and the world. The attachment to isolation, which structures diverse eastern cultures in their relationship with health, religion, leisure and even politics, is a relevant data to understand the recurrent figure of internal exile in his poetry. This is because transit always aims at confinement. Although it is a common feature in the country's literature, which represents nomadic and simultaneously monadic characters, it is worth highlighting the way Patraquim intertwines this problem with the issue of the East since 1980, the year in which Monsoon [Monções], his first poetry book, was published. 
As was seen recently, ${ }^{12}$ Patraquim's literary project can be read as the chronicle of an unsuitable traveller who finds himself in a kind of unconsented loss and who, for this very reason, rehearses a movement. The originality of this gesture lies, among other factors, in a rigorous artistic research on the pulse of Mozambican geography and on the socio-cultural and historical relations that the country establishes with the territories bordering the Indian Ocean and with the world. In this broad record, which in a circular way begins and ends in Mozambique, his reading takes advantage of the artistic potential offered by the imaginary of the abysm ${ }^{13}$ and the monsoon. As we know, in addition to covering much of the territories bordering the Indian Ocean, including Mozambique, the monsoons are commonly related to the wind directions alternation in the rear coastlines of India and the Arabian Peninsula (particularly in the Gulf and in Arabian Sea), where the wind blows from the northeast to southwest during one half of the year and in the opposite direction during the other half. From the moment that he senses the rigidity of certain worldviews, Patraquim organizes a kind of journey that always considers elements associated with this natural phenomenon. At the same time permanent and wandering, inviting both to stillness and to mobility, the monsoon operates as metaphor and as method in Patraquim poetry.

From a detailed work with the instrument of his trip (the language), which foresees the internal logic, the rhythms, the breaks and the semantic slips that are particular to him, Patraquim traces the redoubt of things, especially where lives "the agonic monsoon" (1980), Mozambique. That is, with the same intensity he questions the human being (from anywhere), his poems problematize the powers established and their discursive logic (especially from Mozambique). By intertwining artistic, philosophical and political concerns, his verses confirm that there is still "space for aesthetic operations, even in a world whose meaning already seems given beforehand" (Mammì 2012: 117). In his studies about "what remains" of contemporary art, Lorenzo Mammì defends the following idea: at the moment when an organization and a relation of derivative elements is suggested (the already mentioned "redoubt" of the "agonic monsoon", in the case of Patraquim), the status of things is rethought, and not just their quality of signs or instruments. This type of configuration contributes to reinforce the tense relationship between Patraquim and Mozambique, especially with the old and new ruling elites, but not to overcome the poet's discomfort. On the contrary, the image of the man out of place (like a

12 A general presentation of the poet's work can be read in Can (2018a) and in Can (forthcoming).

${ }^{13}$ As the author himself points out in a recent interview: "And by its nature, it is a country of decentralities... there is a whole coastline that we already know... this one with some relationship with the ocean, with the sea; interiors differentiated from the land, a Y-shape -if you look closely at the map of Mozambique, that is a $\mathrm{Y}-$ which has an abysm within it" (Can 2018b: 11). 
"concave vault in disarray of arches"; 2009: 23), who has no shame in challenging dogmas and at the same time laughing at himself, all of it in an environment marked by contention, is configured as an expression of an impossibility that works as a writing engine.

Indicated in writing or experienced by the citizen, this paradox says a lot about the relationship that the author establishes with his time and with his land. In fact, neither the citizen nor the artist wanted to fit in colonial and postcolonial times. If the insilio - or the internal exile, the strangeness experienced in his own land - is a common feeling to the great names of Mozambican literature, who deal with an art (written) and live in a space (the city) opposite to the practices of the great majority of the population, the case of Patraquim becomes even more paradigmatic: he is the only author among the consecrated authors who also embraced "external exile" in colonial and post-colonial times. Moreover, in both periods he sought "to meet the impossible shadow" (2005: 15) and, from there, as explained by Kareseka Kavwahirehi (2011) in his reflection on exile in post-colonial writing, he reinterpreted the painful break with the homeland and sought to articulate a new discourse on the world and a certain reconciliation with himself. The Indo-Oceanic sociocultural environment, in particular that which condenses on the Island of Mozambique, assumes special relevance in his proposal.

However, a number of variables must be related to Patraquim's exile. Especially because there are a multitude of questions that involve "Mozambique", on the one hand, and "Patraquim" and his poetry, on the other. In addition to inheriting the trapped structure of (already delayed) Portuguese colonialism, suffering a long international embargo and hosting a civil war of astonishing consequences, the country wanted to project on its birth of straight (ideological) fate to a winding land (culturally speaking). As for the author, claiming for literature and for himself a space of autonomy and freedom, he elaborates an art of combinatorics, in which the conversation between East and West, the rigorous disarray and the playful melancholy impact against what was then expected of an intellectual committed to the reconstruction of the nation. Owner of an intuition that feeds on erudition and vice versa, Patraquim focuses on the fragment that induces, suggests or celebrates different names and traditions: "I hear You, Omar Khayyam, amongst crystal shadows" (2011 [2009]: 122). From Iran but also from Sufi poetry, he inherits one that perhaps is his most usual procedure: the confluence of opposites. Based on this strategy, he will dismantle the rigidity of the colonial and post-colonial discourses elaborated in his homeland. Those who find the author's option for artistic experimentation to be parsimony through hermetic formalism or any other form of alienated obedience are mistaken. One of the most inventive and interventional writers of the Portuguese language at the metaphorical, metonymic, allegorical and intertextual levels, his writings can be located in the "in-between" - between the artistic and the political, the individual and the 
collective, Mozambique and the world - and always in that gap that separates desire and the calvary of unfulfillment.

Maputo (in the south, where he takes his first steps) and Island of Mozambique (in the far north, from where real and invented voices emerged), but also Portugal or Brazil, Greece, France or Catalonia (of certain literary references) are some of geographies that Patraquim integrates in his poetics. From his "nomadic home" (2011 [1997]: 73), therefore, this "temple where I surround myself" (2011 [1997]: 81) or "where I blind myself" (2011 [1997]: 81), but with a "peak of monsoon within the eyes" (2011 [1980]: 24), the author lurks the "nerve of the open plains when fauns hit the sound" (2011 [1980]: 17). In effect, because they are covered with humanity, his landscapes of preference implicitly announce the disaffections that the citizen cultivates in the political field. This is the case, in the first place, of Muhipiti, located between the West and the East, but also in a symbolic line diametrically opposed to that of the capital Maputo and the new order that is installed in this place. After all, it is there, on the shores of Island of Mozambique,

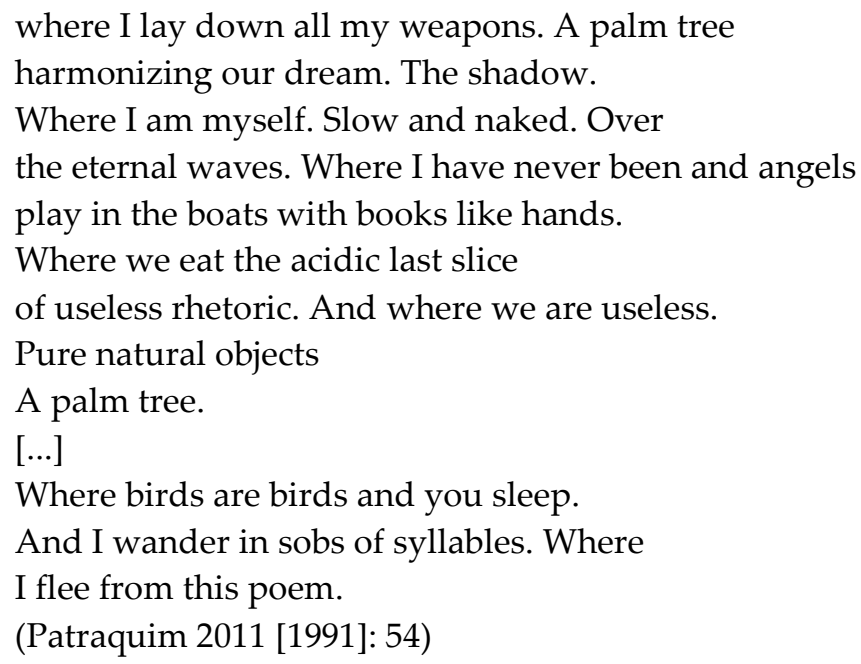

Thus, in the countercurrent of a time that wished to project also the notions of "New Man", "unity" and "vigilance" to literature, Patraquim takes a step back to praise the dispersion, loneliness and delight of the subject, who, in turn, finds himself alone with his fragile humanity. From this angle, he touches and listens to the "stellar caves / to where you flow and, from you, / the lost variation, the delirious breath" (2011 [2005]: 87) of so many other cultural and artistic influences that were unused for a time that opted for a rigid grammar. The poet also turns his back to the voices that narrow the time coordinate around the axis of the "future", offering them the opposite: the "croaky language that sobs in ancient syntagmas" (2011 [1991]: 52) the "mystery of the joints" (2011 [2009]: 123). Dissatisfied with the battle cry of marches, he presents "the sound of the murmur text" (2004), "the exile of the unattainable word" (2011 [2010b]: 148), "the choreographic immobility of silence" (2011 [2010b]: 150) or "just silence in percussion of forms" (2011 [1992]: 69); faced with the 
gesture that reiterates violence, he rehearses "the fire of tact" (2011 [2009]: 123); exasperated by the didactics that point the way, he sings the "sublime scintillation of madness" (2011 [2010b]: 141); uncomfortable with the sacralization of the heroes (and their statues that are cyclically raised and knocked down, according to the moods of the polis), he welcomes the "geological profanations of the soul" (2011 [2009]: 108); baffled, finally, with the one-way political pedagogy, he institutes the poetic performance of multiple senses: "We demand everything: the very guts of the wind" (2011 [1991]: 61). Patraquim embodies, in fact, that ancient tension so well formulated by Ítalo Calvino (1990) between the flame (and the tangle of human existences that he is capable of representing) and the crystal (and the geometric rationality of the city).

Proudly anachronistic, since the chronic exiled is always an anachronistic exiled (Firmat 2013: 428), Patraquim's proposal is based not only on materials that are not compatible with the values that propelled the fragile Portuguese colonial poetry, but as well the nationalist values that guided a writing of militant nature and with "post-colonial" values, which, more recently, paradoxically, have inspired some orientalist poetry. This happens without the author's neglect of the history, culture and uniqueness of the Mozambican experience, nor the need to present concessions to the publishing market and its taste and thirst for exoticisms or authenticities. By twice refusing that claim the image of unity (although with very different arguments and practices), Patraquim recovers the symbolic potential of caesura and, from within, a melancholy but active voice emerges. So intensely experienced in the waters of the Indian Ocean, this caesura - "that hurts like a visiting cloud" (2017: 29) can be observed both in plans of content and form, and not only in what is revealed, but also in what it dissimulates. As if, in the face of the noise of the world, Patraquim wanted to whisper something to us in silence. It is, therefore, in the dialectical tension that brings together the opposites of waiting and movement that Patraquim artistic project finds its way and unity - mimicking, we insist, such monsoons that the author got to know as he fertilized worn-out soils or navigated with the elementary boats on some of his unavoidable voyages. Like the monsoon, in short, his artistic project draws a pattern that is produced by the variation of shapes itself. Contrary, therefore, to the recent history of the country, which, according to his imagination, start in the variation of ways (of action) to maintain the same pattern (of domination).

On a different level, since it is inclined to the aesthetic use of the cliché, which ends up freezing the world of the "other", we observe the way in which the poet Eduardo White integrates the eastern territories in his work, especially in Window to East [Janela para Oriente] (1999). Contexts such as India, Japan, China, Tanzania and Turkey, or Iraq, Kuwait, Iran, Syria and the United Arab Emirates are standardized around an idea of harmony, presenting themselves as the counterpoint of Mozambique. The representation strategy, on the one 
hand, is interesting. After passing through the interior spaces of the roughed house, the nation's metonym, the narrator observes from his window the geography of the "other" with melancholy pleasure. However, this melancholy is of a passive nature. In most prose poems in which the East is present, the buildings acquire interiority and the people, when represented, are seen only from the outside (body parts and clothing). Focusing on the East, this poetry presents some characteristics which paradoxically resemble the orientalist imagination of European artists who in old centuries represented Africa, Asia or the Americas: the absence of a humanized perspective on the landscape; the emphasis given to material culture, which is listed in near litany; the homogenization of disparate realities with the use of a luminous grammar; the resource of the commonplace that masks the historical and constitutive violence of the selected spaces; the repeated use of adjectives which always aim to compensate for the little knowledge about the places chosen. Indeed, the perspective is only changed in the qualitative sphere: from the darkness enacted by the orientalists of the West we move on to idyll. But the East remains static, as if it were about a compact block. Here are two brief examples that bring together all these features and are taken from two works: The Materials of Love followed by The Challenge to Sadness [Os Materiais do Amor seguido de O Desafio à Tristeza], from 1996, and the already mentioned Window to East, from 1999:

I am my Island to the North, the signs and the silks that were exchanged there and in that beauty I look for you and for me some pathway, some underwater and pulsional language, I look for you among black women wrapped in their lift capulanas, tall, thin, fragile and beautiful as the beads and I see you through your absurd blue eyes [...] My love is this fortress, this enchanted Island, these memories on the walls and nobody knows about this pangaio that to the North and the Island brings a nonconformist lover. (1996: 24-25)

I walk through your image like the gem of a diamond so dazzled by the extreme luminosity and I feel the garlic in the markets, the rye paste, the onion closed for the seasoning, the lamb baked. You are so blue in other estuaries, in the dry trees, in the cold night of Baghdad, Salimijah, Shiraz, Latakia and Aleppo, and, at sunset, in a black fire at a refinery in Burgan, so blue, I said, that you already flash to me inside a solar building, the corals of an oasis pregnancy. In a swing in Dubai, I stand and drink, with my hands at the thirst, the hallucinations I had in the Nafoud Desert. Oh my great and beautiful Middle East from where I see Africa from its windows and I hear a beast roar in the savannahs of Mozambique. That is where I should go. Definitely returning [...] So, here I organize the tools of this work, this passion that I have for the visions that I have, for the engine that leads them to the detailed observation of spaces [...] I will close the yellow window that I have facing East. I will restore this miracle of dreaming. In Istanbul a candle is lighten, the look is longing. (1999: 79)

A type of locus amenus and almost always devoid of contradictions, the East of Edward White, which includes the Island of Mozambique of the first fragment, emerges less as the subject of enunciation rather than an object of desire; emphasizes less an immersion in geography and history than an exotic 
re-appropriation of the "other"; 14 in short, it derives less from an effective search for artistic experimentation than from a new form of instrumentalization for its own purposes. If post-colonial criticism tends to give African writing the role of desecrating the colonial imaginary, the stereotype reworked by a writer of White's importance questions this postulate. The repeated inscription of eastern territories paradoxically accentuates the invisibility of the East in his work. This fact confirms the idea that stereotypes, as a strategic negotiating gesture (Garcia 2010: 41-65), a re-appropriation of the other and the foundation of the language itself, ${ }^{15}$ deserve special treatment in African literary studies today. The research on a "late orientalism" (or, if we are allowed an oxymoron, a "post-colonial orientalism"), produced in Africa in a similar way to the one used in imperial literature (even if from a positive and laudatory perspective) does not remove any merit from this work. On the contrary, it adds only a new element for reflection and invites us to observe these authors as an object of study and not automatically as a source of knowledge.

The representation of East African and Asian territories is one of the strongest trends in the Mozambican literary field. This happens in a context of production that does not dismiss dialogue with Western traditions and institutions. As we saw, Mozambican authors are invited to an original mediation movement. But if the eastern dimension is an unequivocal fact of this field of production, the representation of the eastern geographies indicates less the communion than the difference in practices between the writers of the country. This data undermines the myth of uniformity that usually hangs over African literary production, whether it is treated in a broad way (the textuality of the continent) or approached in a particular way (the literatures of each territory). The Mozambican authors confirm, in short, the contradictory nature of the literary institution: it is based on the maintenance of an orthodoxy (one that opposes political orthodoxy) and, simultaneously, it is characterized by constant "internal conflicts of differentiation and renewal" (Dubois 2005: 46) in the modes of expression.

As we saw, in addition to suggesting the plurality of aesthetic records and identity alternatives adopted in national contemporary times, investment in international spaces in the East may result in surprising forms of "late orientalism". The East, in Eduardo White, presents itself as an adornment (resulting from the description or narrative suspension), and not so much as the foundation of history (official or alternative). Actually, the poet seeks to create a regime of truth about the East that serves as a model for Mozambique

\footnotetext{
${ }^{14}$ An interesting analysis of the post-colonial exotic in Mozambican and Portuguese literature and specifically in the works of Paulina Chiziane and Lídia Jorge is made by Martins (2009).

${ }^{15}$ On the forms and functions of the stereotype, read Amossy and Pierrot (1997).
} 
(somewhat in line with what is usually done in contexts of colonial formation in the Americas when they project on the African continent the possibility of their own redemption). In João Paulo Borges Coelho, on the contrary, the East is the resource of a writing that relies on the unsaid and the trace to undermine, through the doxa-paradox interrelation, the celebratory speeches of the "pure race" or the "hybrid race". For Patraquim, in turn, the East works as a kind of zero degree that mobilizes his aesthetic creation. His writing privileges, among many other resources, multiple enumeration to understand the loss or, in the opposite sense, the short verse that seeks synthesis. Whichever option chosen, the ellipse is called to turn up some myths and the oxymoron is invited to found others. Less and less in use after being so finely worked, for example, by some narrators of the Angolan writer Luandino Vieira in the 60s, the strategies used by João Paulo Borges Coelho and Luís Carlos Patraquim place readers, editors, critics and even, say, jurors of literary awards, in discomfort. After all, neither of them corresponds to the conventional expectation that is generated around the "post-colonial" writer, whose implicit mission would be to "give voice to the other", didactically celebrate the margins, establish the explicit pact with the immediate history and, in the limit, as Gayatri Spivak would say, to constitute himself as the new native informant of the western researcher (1999). On the contrary, their works are a kind of fuse that connects the extremes of times to announce a radical change in the Mozambican literary field, one of the most complexes in the universe of the Portuguese language.

\section{BIBLIOGRAPHY}

Amossy, R. \& PierRot, A. H. (1997), Stéréotypes et cliché: langue, discours, société, Paris, Nathan.

APA, L. (1989), «A ilha da memória», in Ilha de Moçambique: convergência de povos e culturas, Angius, M \& Zamponi, M. (eds.), San Marino, AIEP editore, 122-129.

BROOKSHAW, D. (2008), "Indianos e o Índico: o pós-colonialismo transoceânico e internacional em 'O Outro Pé da Sereia', de Mia Couto», in Moçambique das Palavras Escritas, Ribeiro, M. C. \& Meneses, M. P. (eds.), Porto, Ed. Afrontamento, 129-139.

CABAÇO, J. L. (2002), «Ilha cheia de história», Metamorfoses. Revista da Cátedra Jorge de Sena da Faculdade de Letras da UFRJ, 3, 57-64.

CABritA, A. (2017), «A palavra e o silêncio: conversa de tias», Revista Caliban. Retrieved from: <https://revistacaliban.net/a-palavra-e-o-sil\%C3\%AAncio-conversa-de-tiasee19059772aa>.

CAlvinO, Í. (1990), As Cidades Invisíveis, São Paulo, Companhia das Letras. (translated by Mainardi, D., Le città invisibili, Torino, Einaudi, 1972).

CAN, N. A. (2018a), «Patraquim, poesia, tempos: notas sobre um adeus restante», Revista Pessoa, 1, 13-23.

CAN, N. A. (2018b), «Todo poema é uma ilha que deseja ser arquipélago - Entrevista a Luís Carlos Patraquim», Revista Pessoa, 1, 1-12. 
CAN, N. A. (2012), «Os lugares do 'indiano' na literatura moçambicana», in Passagens para o Índico. Encontros brasileiros com a literatura moçambicana, Chaves, R. \& Macêdo, T. (eds.), Maputo, Marimbique, 217-230.

CAN, N. A. (forthcoming), «Luís Carlos Patraquim: 40 ans d'écriture», Cahiers du Crepal, Hors série $\mathrm{n}^{\mathrm{0}} 6$.

CARVALHO, R. D. (2008), A câmara, a escrita e a coisa dita... fitas, textos e palestras, Lisboa, Cotovia.

CHAves, R. (2002), «A Ilha de Moçambique: Entre as Palavras e o Silêncio», Macua. Retrieved from: <http://www.macua.org/coloquio/A_ILHA_DE_MOCAMBIQ UE.htm>.

CoelHO, J. P. B. (2005), «O pano encantado», in Índicos Indícios I. Setentrião, Coelho, J. P. B., Lisboa, Caminho, 11-44.

Coelho, J. P. B. (2020), «The Enchanted Cloth», in A Companion to João Paulo Borges Coelho, Brugioni, E., Grossegesse, O. \& Medeiros, P. (eds.), Oxford, Peter Lang, 11-35. (translated by Brookshaw, D., «O pano encantado», in Índicos Indícios I. Setentrião, Lisboa, Caminho, 2005, 11-44).

CoelHo, J. P. B. (2009), «E depois de Caliban? A história e os caminhos da literatura no Moçambique contemporâneo», in África-Brasil. Caminhos da língua portuguesa, Galves, Ch., Garmes, H. \& Rosa Ribeiro, F. (eds.), Campinas, Editora Unicamp, 57-67.

Couto, M. (2006), O Outro Pé da Sereia, Lisboa, Caminho.

DuBOIS, J. (2005), L'institution de la littérature, Paris, Labor.

FALCONI, J. (2008), Utopia e conflittualità. Ilha de Moçambique nella poesia mozambicana contemporânea, Roma, Aracne.

FIRMAT, G. P. (2014), «Destierro y Destiempo», in Un pueblo disperso: Dimensiones sociales y culturales de la diáspora cubana, Duany, J. (ed.), Cádiz, Editorial Aduana Vieja, 424-430.

GARCiA, M. (2010), «Literaturas Postcoloniales, Hibridación y Exotismo», Prosopopeya, 6, 41-65.

HeRnÁndez, R. (2007), Traducción y Postcolonialismo. Procesos culturales y lingüísticos en la narrativa postcolonial de lengua portuguesa, Granada, Comares.

KAVWAHIREHI, K. (2011), «Penser, écrire l'exil et les migrations postcoloniales», in Exils et migrations postcoloniales. De l'urgence du départ à la nécessité du retour, Fandio, P. \& Tchumkam, H. (eds.), Yaoundé, Ifrikiya, 40-52.

LeITE, A. M. (2003), Literaturas Africanas e Formulações Pós-Coloniais, Lisboa, Colibri.

MACAGNO, L. (2006), Outros Muçulmanos: Islão e narrativas coloniais, Lisboa, Imprensa de Ciências Sociais.

MAMMì, L. (2012), O que resta. Arte e crítica da arte, São Paulo, Companhia das Letras.

MARNEFFE, D. \& DENIS, B. (eds.) (2006), Les Réseaux littéraires, Bruxelles, CIEL-Le Cri.

MARTINS, A. M. (2009), The Postcolonial Exotic in the work of Paulina Chiziane and Lidia Jorge, PhD Thesis, Manchester, University of Manchester.

MBEMBE, A. (2001), «As formas africanas de auto-inscrição», Estudos afro-asiáticos, 23(1), 171-209.

MENDONÇA, F. (2011), «Poetas do Índico - 35 anos de escrita», Mulemba, 3(4), 1-12. Retrieved from: $<$ https://revistas.ufrj.br/index.php/mulemba/article/view/4863>.

NOA, F. (2012), «O Oceano Índico e as rotas da transnacionalidade na poesia moçambicana», text provided by the author. 
PATRAQUiM, L. C. (1980), Monção, Maputo, Edições 70 / Instituto Nacional do Livro e do Disco.

PAtraquim, L. C. (1985), A inadiável viagem, Maputo, Associação dos Escritores Moçambicanos.

PATRAQUim, L. C. (1991), Vinte e tal novas formulações e uma elegia carnívora, Lisboa, ALAC.

PATRAQUiM, L. C. (1997), Lidemburgo blues, Lisboa, Editorial Caminho.

PATRAQUiM, L. C. (2005), O osso côncavo e outros poemas (1980-2004), Lisboa, Editorial Caminho.

PATRAQUiM, L. C. (2009), Pneuma, Lisboa, Editorial Caminho.

PATRAQuiM, L. C. (2010), A Canção de Zefanias Sforza, Porto, Porto Editora.

PATRAQUiM, L. C. (2010b), O escuro anterior, Lisboa, Companhia das Ilhas.

PATRAQuiM, L. C. (2011), Antologia Poética, edited by Carmen Lucia Tindó Secco, Belo Horizonte, Editora UFMG.

PATRAQUiM, L. C. (2017), O deus restante, Maputo, Cavalo do Mar.

RANCIÈRE, J. (2000), Le partage du sensible. Esthétique et politique, Paris, La Fabrique Editions.

SAID, E. (2011), Cultura e Imperialismo, São Paulo, Companhia das Letras. (translated by Bottmann D., Culture and Imperialism, London, Chatto \& Windus, 1993).

SAID, E. (2003), Orientalismo, Lisboa, Cotovia. (translated by Serra, P., Orientalism, New York, Pantheon Books, 1978).

SPIVAK, G. (1999), A Critique of Postcolonial Reason, Cambridge, Harvard University Press.

TANQUEIRO, H. (2003), Autotradução: autoridade, privilégio e modelo, $\mathrm{PhD}$ Thesis, Bellaterra, Universidade Autônoma de Barcelona.

White, E. (1996), Os Materiais do Amor seguido de O Desafio à Tristeza, Lisboa, Caminho.

WHITE, E. (1999), Janela para Oriente, Lisboa, Caminho.

White, E. (2010), Antologia Poética. Nudos, Maputo, Alcance Editores. 